\title{
Chapter 6. Mapping With Metaphor: Cultural topographies in West Timor
}

\section{Andrew McWilliam}

\section{Introduction ${ }^{1}$}

I recall having a discussion some years ago with a group of farmers in the mountains of West Timor; a discussion concerning East Timor and their knowledge of that area. During our conversation I was intrigued by an old woman's comment referring to that part of the island as "the head of the land" (pah in a nakan).

This phrase seemed to imply a system of orientation according to parts of the body, and I later confirmed that, indeed, body symbolism for compass direction was a cultural convention in West Timor. In this system the east, which the Timorese call neonsaet (rising day), and the west (neontes, or setting day) may be associated in certain contexts with head (nakan) and foot (haen) respectively. Similarly north and south are referred to by the terms left (li) and right (ne'u). The implication of this referential system is a prostrate human form with arms outstretched and the head oriented to the east.

This system is a generalized one common to all Meto people (atoin Meto), currently the most populous ethnic group in West Timor numbering over 800,000 people. $^{2}$ As a means of directional reference the symbolic use of the body represents one type of cognitive map by which people orient themselves in the world; it forms one of a number of cognitive reference systems by which people situate themselves in the land, accord significance to places in that landscape, and affiliate themselves within complex social and political networks across the territory.

This paper examines two general cultural constructions of place in West Timor. One form has to do with the association of individuals and of groups to particular named places. The second approach reflects a more abstract mode of expressing place through the use of allusion, the spoken image and the rich repertoire of conventional metaphors which Meto people draw upon to inform social discourse.

\section{Named Place}

The most immediate way people refer to place in Timor is through the use of named localities and topographical features. West Timor is mapped conceptually with a bewildering array of named places, each one carrying the record of some 
remembered ancestral deed or experience. The small mountain hamlet in the old political domain of Amanuban, for example, is called Tukfenu meaning "many headless corpses" in reference to some bloody atrocity committed in an earlier era. A ridge in a nearby village has the name Kelonakaf meaning "monkey head", a veiled reference to the camp site of a returning victorious head-hunting party in the early part of this century.

Most named places, however, suggest more peaceful origins. Many carry the affix "oe" as part of the name. Oe is a Meto word meaning water, and places such as Oe Ekam (Pandanus Water), Oe Nunuh (Banyan Water) and Oe Aiyo (Casuarina Water) are clearly named in reference to the critical importance of water sources for settlement sites in this drought-prone region of Indonesia. Still other places are more prosaic in character: Kae (meaning taboo or prohibition), Maunfunu (meaning chicken feather) and Nis Ana (small tooth) are a few examples. Each of these places names a settlement site, known as a kuan, and projects the record of ancestral experience into the contemporary world.

The knowledge of the naming-of-place stories often resides with people who hold particular claims to land and territory in that area. It follows that some places are of greater significance for some people and groups in Timor than for others. Leaving aside the issue of personal history and life experience for now, the focus here is on the collective knowledge of place and territory recorded and maintained by Meto social groups. It is characteristic of these kin-based groups to preserve a highly selective focus on particular named places which are held to be significant markers of their development over time. In part this is the legacy of a centuries-old tradition of shifting agriculture and the continuing search for new arable land. In addition the disruptive effects of political change, pre-twentieth-century warfare and, more recently, rapid population growth have all contributed to the long term dispersal of kin groups across the region, and the creation of hundreds of small hamlet settlements composed of varying numbers of clans or named group segments.

Meto communities record the movements and journeys of their ancestors through a narrative tradition of oral history in which key places in the clans' expansion and segmentation are remembered and retold. In some cases these narrative stories cover the length and breadth of West Timor.

These histories or narrative stories are a vital part of the process of establishing and reaffirming group identity and status in particular claimed territories; a feature which is highlighted in the persistent concern expressed with origins, political alliances and delegated authority over particular named localities and domains.

In these narrative perspectives on the past, a formal style of speaking is employed which is both poetic and semantically opaque in many cases. It differs from ordinary speech (which Meto call uab meto, or indigenous speech) in the 
pervasive tendency to speak in parallelism or synonymously paired sets of phrases. Meto refer to this formal or ritual style of speaking as natoni. It is the language of ceremonial occasion and ritual discourse, and is expressed in a wide range of formal contexts including traditional prayer and formal dispute resolution as well as marriage negotiations and other life-cycle ceremonies.

It is also in this tradition of formal speech that cultural topographies are most highly developed. Knowledgeable speakers are able to draw upon a rich complex of collective representation and metaphor to create enduring images of place, of event, movement and relationship in the landscape. While the knowledge of, and ability to, narrate "histories" tends to be restricted to senior male members of these dispersed kin groupings, the words of these histories are considered to represent shared true knowledge of the past, upon which resides the identity and claims of affiliation of contemporary living members. Among these recurring images which are invoked in "speaking the past" is one metaphor in particular which seems to encompass and define the nature of all Meto histories. This is the idea of the path or, more correctly in ritual speech, the gate and the path (enon ma lanan), which expresses the pervasive collective concern of Meto communities with connected place and the maintenance of continuity with the past. To relate the origins and history of a name group is to narrate its "gate and path".

\section{Agnatic Paths}

Recounting the origins of the clan in West Timor is, perhaps, better described as tracing the path of the name. This is because all individuals in Meto society are affiliated to agnatically-related kin groups called kanaf, a Timorese word meaning name or name group. Thus when a speaker recounts the history of his group he is, in effect, mapping the journey of a name along a spatial and temporal trajectory which is punctuated by significant events or settlement sites (one notion of the gate) along the way.

At the same time the path of the name is also the temporal path of agnation for the named kin group with its ideology of affiliation through fathers to sons. However, this affiliation tends not to be expressed genealogically in the record of particular generations of named ancestors, but rather spatially across the landscape by associating the group's name with specific places and named localities. Genealogical reference to known ancestors in narrative texts is rare. Indeed, often the speaker will refer to the ancestral figures in the first person $(A u)$ thereby wholly identifying himself with an unbroken passage of the kanaf from its origins to contemporary times. To this extent Meto society reflects a preference for what Fox (1992) has described as a topogenic, as opposed to a genealogical, reckoning of affiliation with the past. In other words the reproduction of the group name is measured or recorded in terms of sequential places rather than a sequence of people. 
I have selected elements of one narrative performance to illustrate some of the images of connected place in the path of the name or name group. They represent random episodes extracted from the narrative and by no means exhaust the poetic possibilities encoded in the oral text. Narratives such as these are in many ways only summary accounts which mark events with key verbal references that may represent tangential points for more detailed exegeses. To the extent that many of the images are collective cultural representations and form part of a common oral tradition they are recurrent themes in the histories of all kanaf groups. For this reason a discussion of the particularities of this narrative and its association with a specific group and named territory is unnecessary. Suffice it to say that the narrative belongs to an influential name group in the southern central highlands of West Timor known as Southern Amanuban. The narrative segments are drawn from a longer "history" provided by a senior ritual speaker who performed an account of his "gate and path" to clarify the former political structure of the domain.

\section{Episode I: Origins}

Afi neon unu
ma fai unut ne
Hai Nai antokom bi
fatu Saenam
am oe Saenam.
Bi fatun
tal fatun

Saenam am Oenam

Banam am Onam.

\author{
In the ancient days \\ and the ancient nights \\ our ancestor lived at \\ the rock of Saenam \\ and the water of Saenam. \\ At the rock name \\ the shading rock name \\ Saenam and Oenam \\ Banam and Onam.
}

This segment of ritual speech marks the beginning of the narrative. It is typical of the dispersed kanaf groups of West Timor to associate their mythical origins with one of the numerous prominent limestone outcrops which are scattered throughout the region. For the speaker of this narrative and for the collectivity of his name group, the rock of Saenam represents the ancestral origins of the group. All members of the group refer to themselves in certain formal contexts using the rock name (fatun) of Saenam. Kanaf groups which share common "rock of origin names" are believed to have originated from the same place. It is consistent with the topogenic character of Meto origin journeys that the ancestor in the narrative segment is not named as such. What is marked is the place of origin and the narrative device of merging person with place.

The final couplet of the narrative segment refers to four names. These represent the ritual names of four large, former political domains in central West Timor, namely Miomafo, Molo, Amanuban and Amanatun. ${ }^{3}$ The verbal marking 
of four names is a cultural convention for representing notions of unity and completeness, and is generally associated with aspects of ritual and political alliance. Once again the terms evoke a complementary dualism between people as political communities and places as political domains.

\section{Episode 2: Journey}

$\begin{array}{ll}\text { Es ne naek Atoni } & \text { As a great man } \\ \text { atik paham } & \text { one who kicks the land, and } \\ \text { atik nifu } & \text { one who kicks the water } \\ \text { leuknan } & \text { travelling past } \\ \text { petu ini holain ma } & \text { the slippery bamboo and } \\ \text { noe ini hokan } & \text { the swollen stream } \\ \text { Amsam Noetasi } & \text { Amsam Noetasi } \\ \text { Monam Salbet. } & \text { Monam Salbet. } \\ \text { Kantokombin } & \text { Not staying long } \\ \text { kan nonembin } & \text { not remaining [but] } \\ \text { tipuon } & \text { turning back } \\ \text { nao natuina. } & \text { returning from. } \\ \text { Funam in saen } & \text { The rising moon } \\ \text { am neno in saen. } & \text { and the rising day. } \\ \text { Li'on fain neman } & \text { Bending back one way } \\ \text { tipu'on fain nem. } & \text { turning back the other. }\end{array}$

In this segment the terms pah and nifu from the conventional paired expression for the land, in much the same way that the Indonesian phrase tanah air is used to encompass the land and water resources of the nation. The ancestor of the narrator is identified as one who "kicks the land and water". The conventional Meto meaning of the term natik is to kick, but it is usually associated in ritual language with a capability to expand the territory through force and particularly through head-hunting. The idea that the ancestor is a head-hunter is supported in the following couplet by the obscure reference to "the slippery bamboo and swollen stream". This phrase represents a mnemonic or marker which can form the basis for further explication. It is associated in this case with the story of how the ancestor obtained the ritual power to become a feared head-hunter and gained what is termed the kan le'u or the sacred, awe-inspiring name of the group, which is used to this day. ${ }^{4}$ Given that it is not permissible to speak of the original name of the kin group, this form of phrasing may also serve to mask an event which should not be spoken of directly.

Finally the evocative image of li'on and tipu'on neatly expresses the process of a group wandering across the land in search of a place to settle. The terms 
refer to weaving techniques: $l i$ 'on is a method of bending a plait back in on itself, and tipu'on has a similar meaning except the woven strip is snapped back and secured. The verbal image therefore expresses a movement somewhat akin to an S-shape; a wandering without security of tenure.

\section{Episode 3: The gate of Tumbesi}

Tiaman tok, nak

pah $i$ suis leuf

am ma'len leuf.

Mas, of tahat kalekofa

ma tinut kalekofa.

mautum, hit nao neo

toi manuan am

eno manuan es ne

fatu Tumbesi ma

hau Tumbesi.
Reaching there, saying

this land is very thin

and very confined.

Later [we] will eat poorly

and drink poorly.

So be it, we will go to

the wide stile and

the wide gate that is

the rock of Tumbesi and

the tree of Tumbesi.

This third example expresses several important collective representations of place and topography. Ma'lenat (meaning confined or narrow) and manuan (wide and expansive) are concepts frequently associated with motivations to shift to new settlement areas. When areas become overpopulated and garden land is in short supply, disputes and fighting among neighbours and relatives increase, and the land is said to become narrow (ma'lenat). One strategy to overcome this situation is to move to less populated forest areas and to establish new settlements. These thinly populated frontier areas are said to be wide or broad (manuan). The historical movement of Meto populations from the narrow confined lands in the eastern mountains to the wide open country in the west represents a continuing feature of Meto society. Present day population pressures and environmental degradation has, if anything, increased this trend.

In the segment above, the pairing of eno and toi as the "wide gate" and "wide

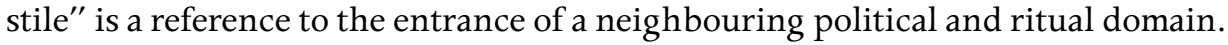
Today the conventional meaning of eno is simply a door or doorway. However, in the above sense the ritual meaning of eno has mostly to do with the main gateway or boundary entrance to a different political community. One typical feature of Meto political structures was the appointment of warrior groups known as meo (cat) to guard the conceptual "gates" of the domain from incursions by enemy groups (see McWilliam 1996). In this case, the "wide gate" refers to the domain of Amanuban because it is associated with the former ruling centre of the polity, Tumbesi. In the past Amanuban was a large and sprawling domain which, in part due to its size, was frequently torn by internal unrest and feuding. 
In associating Tumbesi with the "rock" and the "tree", the narrative description identifies the named place as a ritual and sacrificial centre. In traditional Meto religion, the pairing of "rock" and "tree" explicitly refers to sacrificial altars which took the form of large trees with stone altars secured at the base, or forked wooden posts in which altar stones were secured. These sacrificial sites were foci for rain-making and for harvest ceremonies associated with agriculture and the complex of rituals related to name-group life-cycle ceremonies and to head-hunting cults. One shorthand term for Meto religion was hau le'u faut le'u, which may be glossed as "the sacred tree and sacred rock or stone" (see McWilliam 1991).

The special importance of Tumbesi here is that it establishes a political connection between the kanaf group of the narrative and the old ruling centre of Amanuban, which represents the source of its subsequent claims on territory within the domain. The remaining episodes in the narrative relate this process of establishing claim and securing political allies in the southern part of Amanuban.

\section{Episode 4: The ordering of people and place}

Aet pilun u fani
ma aet so'it ma solo
onat futun suan
bi neo lana Teas ini
na panat Teas
onan apao
hue sufan
usaip sufan
bi nepo kotin
ma nenu kotin.

Take the head wrap and axe and take the hair comb and silver coin to tie in the roof spar at the path of Teas the platform of Teas to become the guardians [of] the flowers of the hue tree the flowers of the usaip tree at the outside fence and the outside boundary.

This final illustrative segment is chosen arbitrarily from the oral testimony as an example of the way allies of the narrative-owning group are placed within the territory. Just as the ancestors of the speaker are said to have been directed to settle an area by the ruling centre of Amanuban, a settlement they achieve by "spearing the wild birds and feral chickens and evicting them from the land", so the ordering of allies within the territory is represented as a form of directing and delegating (malek anmalul) subsidiary groups to defensive places within the new political territory. By this process an order of social and political precedence is established whereby rights to settlement areas and land devolve through the direction or permission of more central, higher-order authorities. In this way claims on land and place may be said to be "nested" in the prior rights of more senior groups. 
There are three aspects of the above segment which highlight specific Meto cultural notions of place. The first five lines are references to settlement and the implied establishment of food gardens in the area known as Teas, presently a formally constituted village in south central Timor. Second, this place is located at the periphery, the "outside fence and boundary" of the domain in relation to the central position occupied by the narrator's ancestors. To this extent the narrative reflects a typical Meto conception of politico-ritual order whereby the centre or "navel" of the domain exerts authority outwards at a diminishing rate until, at some point on the periphery, a rival centre exerts a stronger attraction. In the turbulent period of the nineteenth and early twentieth centuries in particular, the prevalence of predatory raiding and head-hunting by rival political communities required the positioning of strong defensive outposts.

Third, there is an otherwise obscure reference to the hue and usaip trees. The meaning of this couplet is related to the harvesting of wild honey beehives (oni naus) and the bees' wax they contain. Formerly in Timor bees' wax provided a lucrative export commodity supplying the flourishing Javanese batik industry, particularly in the nineteenth century. Often these wild hives were located in the forested buffer zones which separated competing political interests. In the narrative the ally is sent to guard this economic resource and in return for rights to settle and cultivate the surrounding land, it would offer up the harvested bees' wax as tribute to the centrally located ruling group. ${ }^{5}$ Though semantically condensed this episode provides a fine example of the poetic construction of place in the context of a political order.

The narrative performance from which these episodes are drawn does not end in the present day. Rather it culminates in an unspecified time in the past when the name group had secured a position of relative autonomy and independence within its new territory and had claimed the political title of Lord of the Land (Pah tuaf). Since that time new hamlets have evolved and segmented in the continuing dispersal of groups across the region, creating further minor extensions to this primary path of the kanaf group name. Reference to the central narrative is made by orientation to what is termed "the old settlement and the old place" (kuamnasi ma balemnasi) where the ancestral name resided in the past and where today small groups of old people linger on, preserving the links to the past and guarding ancestral heirlooms and graves.

Among contemporary groups that identify with the particular narrative discussed above and the record it preserves, the legacy of the narrative past is an enduring one in at least two important ways. First, the oral testimony is a measure of the name-group identity linking a name with the significant places and relationships along its journey of origin. Second, it serves as a legitimizing discourse and statement of claim to the land which it occupies and accepts as an inherited right. 


\section{Affinal Paths}

In recounting the narrative path of the name group, mention is sometimes made of political alliances founded on the basis of marriage exchange. It is unusual, however, for specific affinal ties to be mentioned in the context of narrative history. Yet the very existence and reproduction of the exogamously constituted name group is dependent upon the flow of life which derives from women, as wives and mothers, who marry into the name group from outside. This is a cultural imperative in Meto society, and one also represented through such conventional metaphors as a path (lanan). The path of alliance is symbolic of the fertility that one name group passes to another. It encodes the polysemic image of the trodden path that links affines across space and between place as it intersects the path of agnation and enables it to continue. This is why wife-giving affines are referred to as "mother and father givers of life" (en amahonit ma am amahonit).

A starting point for appreciating the nature of affinal paths in Meto collective representation is the perspective from the house and hamlet. The conical thatched house (ume kbubu') and the cluster of nucleated households which constitute the hamlet (kuan) represent the primary level of socialized space in Meto society - a domesticated centre where most social life is conducted and negotiated (see Fox 1993).

The orientation of the Meto house is based on a three-level, concentric model of ordered space. The house itself is central and referred to as inside (nanan). This is a classifactory female space associated with food storage and preparation as well as with sleeping and childbirth. In contrast the area immediately outside the front door is termed mone, the word also used for "male" or "masculine". While Meto do not make this association explicit the conceptual link of male/outside and female/inside is strongly implied. One Meto aphorism for example holds that a woman's role is to guard the house and its contents (bife apanat poni), while a man's role is to seek income and wealth outside (atoni naim noni).

Beyond the houseyard, or more specifically beyond the sturdy fence which typically marks the houseyard boundary, everything is termed kotin, meaning "outside" (or literally "behind", connoting that it is out of sight). The realm of the outside (kotin) is symbolically associated with the unknown, with strangers, enemies and spirit entities.

These conceptual markers of place or space are also relative terms for delineating degrees of inclusion and exclusion. The house, for instance, may be conceptually inside (nanan) in relation to the hamlet, while in a different context, the whole hamlet may be nanan in relation to the wider world of village and political domain. The contrast implies a distinction between the ordered, familiar, domestic sphere of the inside - conceptually a female place - and the uncertain, 
untamed and potentially dangerous realm of the outside - conceptually a male space.

One example of how this conceptual order is realized in practice is seen in the way Meto deal with what has been termed bad death (see Hertz 1960; Fox 1973). All violent, unexpected and sudden deaths are considered ritually threatening and are treated as "outside (or male) deaths" (maet mone) by Meto communities. Such instances should be treated in ritually prescribed ways to render them spiritually harmless. These deaths are distinguished from the relatively benign deaths of the "inside" (maet nanan) as a result of expected or at least not inexplicable deaths.

The same focus on categories of inside and outside are also invoked in the cultural representations of marriage exchange and alliance. In Meto kin terminology the classification of matrilateral and patrilateral cross cousins is termed the wife path (fe lanan) and the husband or male path (moen lanan). These are clearly favoured marriage unions and when occurring may be described as "marriages within the house" (matsao/nakaib ambi ume nanan). Alternatively they are described as marriages which "strengthen the roof of the house" (na li suaf am takpani, where suaf refers to a roof spar, and takpani are the forest vine ties which encircle and secure the spars). In other words the metaphor of the path which characterizes the joining of separate groups in marriage is transformed into the metaphor of the house when such alliances are reaffirmed through subsequent cross-cousin marriage. Affines may then be said to live in one house, or under one roof, with all the mutual ties of obligation and reciprocity that this implies.

In contrast, marriages which are negotiated between groups without affinal links are referred to as "from the outside" (nako kotin) or alternatively "from a different rock" (nako fatu es, or rock of origin). Because of the social and sometimes geographical distance involved marriage negotiations in these cases are more protracted and usually involve more substantial marriage gifts. These types of marriage are described in the following segment of ritual speech in which the prospective groom is said to

laka noe

ma sae bahan

on a ma'fe bi mata teme

am ma'fe ila teme. cross the river

and climb the fence

for a stranger eyed wife

and a stranger faced wife.

The images here are typically Meto and express important cultural notions about the transformation of strangers (and by inference, enemies) into affines through the connecting of place by paths of alliance. The phrase lak noe (to cross the river) is frequently used to represent social and geographical distance. Rivers 
are often boundaries between political domains and territories, and while contemporary economic and political change has led to the weakening of the former insularity of social life, most Meto farmers are reluctant to marry outside older established patterns of social networks. The second image of "climbing the fence" is partly an allusion to one of the stages in the ceremonial process of marriage termed "to climb the stile and descend the steps" (sae toi ma sanu se'at), which refers to the proper etiquette of marriage negotiation, where one formally enters by the front gateway to the houseyard in the "light of day" (neno pupu), as opposed to marriage by ritual abduction (mnaenat) where one is said to "go stealing women in the night" (nao nok fai ma nabak bife). In the third image the term teme, which I have translated as "stranger", literally means "round". The image of one being round eyed and round faced portrays the expression of shock and surprise at seeing outsiders.

The joining together of potential affines in marital alliance is expressed in the formal process of marriage negotiation where, typically, a senior arbitrator is appointed to facilitate the union of marrying groups. He is referred to as the nete lanan, literally the "bridge path", and he provides the role of "smoothing the path" in the sometimes delicate negotiation of the terms of the marriage exchange. The complementary notion of the gate is epitomized at the main marriage exchange ceremony when the wife-takers mass at the front of the bride's houseyard and request the opening of a ceremonial cloth gate (klibat klabat), which is erected to block the path. This is the first of three cloth barriers which are erected to shield the bride from the groom. Ceremonial exchanges to open (nasoetan) the remaining gates at the house proper and across the entrance to the room where the bride waits are both accompanied by ritual dialogue and the offering of prestations. This appropriation of the wife-mother sets in train a life-long process of gift giving and the provision of labour services to acknowledge the gift of life and to keep the "path of alliance" open.

The path created by marriage is also the pre-eminent symbol of continuing alliance, and the sum of affinal relations which are recognized by any one Meto house or name-group segment is the total number of active "paths" (lanan) which radiate out in the form of married sisters and daughters of the name group. The image is a compelling one which is continually reinforced and reaffirmed through the conduct of important ceremonial and ritual contexts when the various wife-taking affinal groups are called upon to fulfil their obligations to the life-giving house and kanaf group. So, for instance, in times of death, the family is said to "send out the feet" (tapoitan haef) in the form of younger men who go to inform the various affinal "paths" of the kanaf group of the death. This engages the obligations of the wife-taking houses who come to grieve and deliver gifts of meat and rice. In so doing they fulfil the cultural expectation that a wife-taker should not arrive at his wife-giver's house with "empty shoulder and empty hand" (kan ben lumaf ma kanim lumaf). 
At the same time the knowledge of affinal paths fades with time. This is in part the consequence of not renewing earlier alliances with subsequent marriage exchanges. It is also probably a consequence of the importance accorded a patrifilial ideology whereby the path of the name has a permanent enduring quality at once stable and immutable over time, though ultimately sterile because it may not procreate with its sisters and daughters. This path is intersected by and contrasted to the mutable and numerous more ephemeral affinal paths which, having transferred the gift of fertility and life from one name-group to another, may lapse and be forgotten unless renewed or kept open by subsequent marriage exchange. ${ }^{6}$ In these intertwined spatial images of process and relation the metaphorical mapping of social paths across the landscape provides a cultural reflection of the mountains of Timor with its networks of narrow footpaths that link hamlet to hamlet, people with place, and the major gateways which tie larger ritual and political domains to one another.

\section{References}

Fox, James J.

1973 On bad death and the left hand: a study of Rotinese symbolic inversions. In R. Needham (ed.) Right and left: essays on dual classification, pp.342368. Chicago: The University of Chicago Press.

1992 Genealogy and topogeny: towards an ethnography of Rotinese ritual place names. Paper presented at the annual Australian Anthropological Society Conference, 1992, Canberra.

1993 Memories of ridge-poles and cross-beams: the categorical foundations of a Rotinese cultural design. In J.J. Fox (ed.) Inside Austronesian houses: perspectives on domestic designs for living, pp.140-179. Canberra: Department of Anthropology, Research School of Pacific Studies, The Australian National University.

Hertz, R.

1960 Death and the right hand. London: Cohen and West.

McWilliam, Andrew

1991 Prayers of the sacred tree and stone: aspects of invocation in West Timor. Canberra Anthropology 14(2):49-59.

1996 Severed heads that germinate the state: history, politics and headhunting in Southwest Timor. In J. Hoskins (ed.) Headhunting and the social imagination in Southeast Asia, pp.127-166. Stanford: Stanford University Press.

Middlekoop, $\mathrm{P}$. 
1960 Curse retribution and enmity, as data in natural religion, especially in Timor confronted with the scripture. PhD thesis, University of Utrecht. Traube, Elizabeth

1986 Cosmology and social life: ritual exchange among the Mambai of East Timor. Chicago: University of Chicago Press.

\section{Notes}

1 A version of this paper was presented at the annual Australian Anthropological Society Conference in Canberra, 1992.

2 This ethnic group is referred to variously in the literature as the Atoni, Atoni Pah Meto, Dawan or simply Timorese. I prefer the term Meto, which has the meaning of indigenous and is usually contrasted to the term kase meaning foreign. Hence the common phrase Hai atoin Meto (we Meto people) as opposed to atoin kase (foreigners or all other non-Meto people). The term atoin is the metathesized form of the word atoni.

3 The names of each of these political or territorial entities in turn can be expressed more completely in ritual language. The formal term for Amanuban, for example, is Banam or rather Bunuh bi teno nenu Banam, which is itself a kind of exegetical code alluding to the mythical origins of the domain.

4 Middelkoop (1960) provides a useful discussion of the nature of the $l e^{\prime} u$ complex in Timor.

5 It was symbolically appropriate that the ruling centre in this context was said to receive the white wax head (oni in a nakan) as tribute from its allies. Metaphorically the ruler was the "head" (nakaf) of the political body in much the same way as the concept is used in Western political expressions. As such the ruler received "head" portions of commodities as tribute, including the noni nakan or "head money" received for the sale of sandalwood, and the "heads" of maize and rice as harvest tribute not to mention the severed and smoked heads of human enemies.

6 A similar idea is expressed by Traube about the Mambai of East Timor whose culture has many parallels with the Meto in the west (see Traube 1986:96). 